\title{
Potential Contribution of Drones to Reliability of Kenya's Land Information System ${ }^{1}$
}

\author{
Patricia Kameri-Mbote \\ Professor, School of Law, University of Nairobi
}

\section{Muriuki Muriungi}

Tutorial Fellow, School of Law, University of Nairobi; and MSc Candidate, University of Oxford

\begin{abstract}
Kenya has sought in recent years to digitise its land information system in order to increase reliability and accessibility, both of which are critical to securing land rights, minimising land disputes, and increasing investment in the sector. This thematic report argues for deployment of drone technology in order to increase the reliability of Kenya's digital land records.
\end{abstract}

\section{Keywords}

land information system, land records, surveying, mapping, land rights, land disputes, digitisation, drones, Kenya

DOI: https://doi.org/10.23962/10539/23500

\section{Recommended citation}

Kameri-Mbote, P., \& Muriungi, M. (2017). Potential contribution of drones to reliability of Kenya's land information system. The African Journal of Information and Communication (AJIC), 20, 159-169. https://doi.org/10.23962/10539/23500

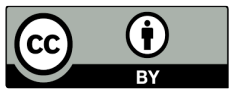

This article is licensed under a Creative Commons Attribution 4.0 International (CC BY 4.0) licence: http://creativecommons.org/licenses/by/4.0

1 Elements of this thematic report were presented in draft form at the Annual World Bank Conference on Land and Poverty, 20-24 March 2017, Washington, DC, https://www.conftool.com/landandpoverty2017/index.php?page=browseSessions\&form_session=594\#paperID333 


\section{Introduction}

Kenya is engaged in spirited attempts to digitise its land records. The manual system was fraught with multiple challenges: human error, opportunities for corruption due to missing files, incomplete land information, difficulties in accessing records, and cases of multiple titling - all of which served to make land rights generally insecure in Kenya. The Ministry of Lands and Physical Planning has embarked on an ambitious process of digitising existing land records, in a bid to enhance both data reliability and security of tenure.

In addition to digitisation of existing records, we propose increased use of drone (unmanned aerial vehicle) technology in support of land mapping, particularly in remote areas, in order to enhance the accuracy of the data in the registries that are in the process of being digitised. The data obtained through the use of drones could facilitate more accurate delineation of boundaries among land holdings, thus minimising contestation. Unlike maps created through traditional surveys, those generated through the use of drone technology have more details, enabling the recognition of various landmarks and buildings (Asian Survey and Mapping, 2016). Another advantage of drone technology is that it is rapid, enabling mapping and surveying of as many as 40 hectares in a single day (Asian Survey and Mapping, 2016).

Up to $60 \%$ of surveying costs under the traditional surveying method are the logistical costs incurred by a survey team (Almenteros, Arnante, \& Dealca, 2016). Using drone technology eliminates the need for on-the-ground logistic teams, thus obviating these costs (Almenteros et al., 2016). Moreover, drones are able to map large areas in a short span of time, thus enabling rapid land-mapping and titling.

\section{Land information in Kenya}

Kenya's antiquated manual land information system is traceable to 1902 when the then-Recorder of Titles under the British colonial regime used to keep titles under the Registration of Titles Act (RTA) system (Wayumba, 2013). These paper records are prone to wear and tear, loss, theft, being hidden, or even being deliberately misplaced. The manual land recording system has also been associated with double allocation of title for a single piece of land, missing files, and erroneous (sometimes fraudulent) transfers of titles (Business Daily, 2015). Frustration encountered by people transacting land rights has acted as a disincentive to engaging and investing in the sector (Ayodo, 2014). A simple search may take over a week due to bureaucracy and interference by cartels and brokers who seek to benefit from the system (Ayodo, 2014). The Doing Business in Kenya Report 2016 was critical of Kenya's dearth of digitised land records, particularly outside Nairobi (World Bank, 2016).

The tenacity of Kenya's manual land records in registries around the country is remarkable considering the digitisation efforts that have been pursued over the years (Mutiga, 2009; Mbaka, 2013; Wanzala, 2015). The failure to secure a fully digitised 
land information system can be attributed to: resistance by actors within the land sector who perceive digitisation as a threat; lack of adequate human and financial resources; lack of political will and leadership; and torn, missing and incomplete land records (Mbaria, 2009; Ntonjira, 2016).

Following the post-election violence of late 2007 and early 2008 occasioned by a disputed Presidential election and the identification of land disputes as a contributing factor to the violence (Kameri-Mbote \& Kindiki, 2008), land reform emerged as an agenda necessitating immediate action. This fed into the finalisation of the National Land Policy in 2009, which, inter alia, called for digitisation of land records to avert fraud (Ministry of Lands, 2009). This was not the first time that computerisation and digitisation of land records had been suggested (see (Republic of Kenya, 2008), but inclusion of this matter in the National Land Policy signaled a more serious consideration, and digitisation is now a statutory obligation, as enshrined under sections 9 and 10 of the Land Registration Act of 2012.

According to the Land Governance Assessment Framework (LGAF) Report of 2014-2015 prepared for the World Bank, which assessed the status of land governance in Kenya, the manual land-recording system is inefficient, time-consuming and militates against timeous decision making (Kameri-Mbote, 2016). A Commission set up to investigate illegal and irregular allocations of land in Kenya found that that uncertainty generated by multiple titles over single pieces of land "has the potential of disrupting the land market and jeopardising the general development of the country" (Republic of Kenya, 2004).

Meaningful social and economic development are threatened in the absence of secure land rights (Besley \& Ghatak, 2009), which in turn are dependent on reliable and easily accessible land information. Recent contestations over ownership of prime pieces of land in Nairobi are apt illustrations of the problematic nature of land governance in Kenya and the difficulties that arise in determining the ownership of land in the absence of reliable information. A scandal relating to alleged "grabbing" of a 144-acre piece of land in the prime Karen estate in the south of Nairobi is a case in point (Nyassy, 2014). Various individuals claimed ownership of the land, and some had sold the land to third-party purchasers (Nyassy, 2014). Politicians and other leaders were allegedly linked to the fraud, but investigations to determine the real owners of the land were unsuccessful (Nyassy, 2014).

Similar disputes have arisen over land in Nairobi's prime Westlands and Parklands areas, regarding renewal of leases (Achuka, 2016; Mutavi, 2016). Instances abound where cartels are alleged to have colluded with officials from the Ministry to put up notices requesting application for renewal of leases on parcels of land, in default of which they dispossess owners of the land (Mutavi, 2016). There is also evidence of cases where lessees whose leases are expiring and who should have the first right of 
reversion are evicted violently (Ombati, 2016).

Contestation over ownership of land allegedly belonging to the United States International University (USIU), pitting a former President of Kenya Daniel Moi against two investors, also sheds light on the lack of clarity on land ownership (Agoya, 2016; Wasuna, 2016). Lands targeted by cartels have even included lands housing public entities. Such was the case in the Lang'ata area of Nairobi when land belonging to a public primary school was at issue (Muthoni, 2015).

Thus, the importance of reliable and publicly accessible land information cannot be over-emphasised. At present in Kenya, surveying for cadastre maps (maps showing land ownership and boundaries) is largely done through varying spatial referencing systems by physical surveyors (Wayumba, 2013). This has contributed to difficulties in integration of survey plans to create a seamless map (Kuria, Kasaine, Khalif, \& Kinoti, 2016). Survey data such as Registry Index Maps and survey plans are not in a common referencing framework, resulting in inconsistencies in the interpretation of survey plans and disputes (Kuria, Kasaine, Khalif, \& Kinoti, 2016). Cognizant of these shortcomings, the Ministry of Lands and Physical Planning's National Spatial Plan is seeking to modernise land registries (including making them more publicly accessible), is establishing a Kenya National Spatial Data Infrastructure (KNSDI) centre, and has embarked on various processes to build an updated, easily accessible and reliable National Land Information Management System (NLIMS) (Ministry of Lands and Physical Planning, 2017; GSDI, 2016). The NLIMS processes include digitisation of land paper records in various registries across the country (Daily $\mathrm{Na}$ tion, 2017). In order to digitise land records, the Ministry has in particular operationalised an Electronic Records Management System (ERMS) and up-scaled the digital access systems (Ministry of Lands and Physical Planning, 2017). It is worth noting that the Ministry has on different occasions disrupted normal services at its headquarters in Ardhi House, Nairobi to load its land paper records onto electronic platforms in a bid to digitise (Omulo, 2017). Various registries including Kisumu, Meru, Mombasa, Kwale, Kilifi, Eldoret, Bungoma, Kiambu, Thika, and the Central Registry in Nairobi, are digitised, in a process that began in September 2016 (Omulo, 2017).

The Constitution of Kenya of 2010 provides in Article 35(1)(a) for the right to access information held by the State and other persons, especially where it is required for enforcement of one's fundamental rights and freedoms (Republic of Kenya, 2010). To implement this provision, Kenya enacted the Access to Information Act 31 of 2016, which provides that the government or a public authority shall provide the information requested within 21 days of such request (sect. 9), unless such request falls within any of the listed exceptions (sect. 6) (Republic of Kenya, 2016). Kenyan individuals or corporations may lawfully demand information from public entities 
including the Ministry and other state entities responsible for land administration and governance.

Article 60 of the Constitution recognises secure land rights, indirectly imposing a duty on state entities to ensure that they have proper and reliable records in this regard. Section 7(2) of the Land Registration Act 3 of 2012 provides that the Registrar of each Land Registry shall make information relating to land accessible to any person upon payment of the prescribed fee (Republic of Kenya, 2012). Section 9 of the same statute provides that the Land Registrar shall maintain the register and any document in a secure, reliable and accessible format, including electronic files. Section 10 provides that subject to the right to access information under the Constitution, the Registrar shall make information accessible to the public by electronic means or other means as prescribed by the Chief Land Registrar. These statutory provisions mandate state agencies to put in place mechanisms to facilitate the relaying of updated records and to enhance accessibility by the public. The National Broadband Strategy identifies the digitisation of land registries and the development of the aforementioned KNSDI as focus areas for implementation.

\section{Drones and mapping of land information}

Mapping land information using drone technology involves the use of GPS-enabled drones to conduct aerial surveys. Drones are able to capture high-resolution images, which are then used by land planners to not only identify, but also digitise the record of boundaries of any land (Pablo \& Petzold, 2016). Drones' advantages over the traditional methods of mapping are: increased speed, increased reliability, and fewer costs than with sending surveyors out to physically map (Pablo \& Petzold, 2016). Drones also have the advantage of easily reaching remote, largely unsurveyed areas (Pablo \& Petzold, 2016).

Drones have been previously employed in Kenya for recreational activities such as photography and security (Bonyo, 2015). Their use was, however, halted by the government in 2015, pending the promulgation by the Kenya Civil Aviation Authority (KCAA) of regulations to guide their usage and address possible breaches of security and infringement on privacy (Johnson, 2015). The KCAA finalised rules in 2017 (KCAA, 2017) to guide the licensing, approval and flying of drones in Kenya (Kuo, 2017). Various license-seekers, estimated at around 1,000, prompted the drafting and approval of the regulations to use drones for various purposes (Andae, 2016). For instance, the O1 Pejeta Conservancy had sought permission to use drones to fight poaching (Andae, 2016). In the regulations, the KCAA has categorised the use of drones into: those for recreation and sports; for private use excluding sports and recreation; and for commercial activities (Njoroge, 2016). The agency also classifies drones in accordance with their weight and uses in the rules, which also impose criminal liability for breach (Njoroge, 2016). The regulations have filled the 
regulatory vacuum, which, without doubt, hindered further acquisition and usage of the technology for various beneficial purposes.

Several countries have harnessed drones to enhance the reliability and accessibility of their land-mapping. We now describe two such examples, in Tanzania and The Philippines.

\section{Tanzania}

In 2014, Tanzanian media reported several clashes over land among farmers in the country's northern Maynard region (Makoye, 2016). In 2016, it was reported that farmers in the southwest region of Morogoro killed hundreds of livestock on grounds that the livestock-owners had let the animals roam onto their land and destroy their crops (Makoye, 2016). These conflicts were to some extent caused by unclear demarcations of land boundaries (Makoye, 2016). It was this challenge that the Tanzanian government sought to overcome using drone technology. In a project supported by the World Bank and the Tanzania Commission for Science and Technology, boundaries were mapped with drones and over 300,000 land titles were issued to citizens (Makoye, 2016).

The initial use of drone technology in Tanzania, before its use in land-mapping, was for mitigation of the effects of floods in the capital Dar es Salaam. With over 70 per cent of the population in the capital living in informal settlements prone to flooding (Soiselo, 2016), drones were used to help to generate accurate maps of the localities and thus assist administrators in drawing up accurate plans to protect persons at risk in flood-prone areas (Makoye, Drones help communities map flood risk in Dar es Salaam slums, 2017).

\section{The Philippines}

The Philippines has applied drone technology in mapping land for surveying and titling (Asian Survey and Mapping, 2016). The country has around 24 million parcels of land, of which only about half are surveyed and titled (Pablo \& Petzold, 2016). The high costs associated with surveying land were cited as one of the reasons for the many pieces of unsurveyed and untitled land (Pablo \& Petzold, 2016). In a bid to accelerate the process of titling, the Asia Foundation partnered with the Foundation for Economic Freedom and Omidyar Network in a project that used drones to conduct land surveys (Pablo \& Petzold, 2016). A study found that use of drones was more cost-effective and faster than the conventional surveying methods (Almenteros et al., 2016). The study recommended a policy change in Philippines to allow the use of drones as one of the official techniques in land mapping and surveying (Almenteros et al., 2016) 


\section{Recommendations}

There are several steps that the Kenyan government should take so as to be able to use drones in support of development of a more reliable national land information system. The aforementioned KNSDI is only possible through the prudent use of information and communication technologies (ICTs) (Odongo \& Rodriques, 2016), and drones need to be among the ICTs used.

The Ministry of Lands and Physical Planning should apply to the Communications Authority of Kenya for authorisation and spectrum allocation for use of drone technology to capture land-mapping data. At the same time, land data generated through drone technology can only be reliable if it is protected from hacking and tampering, both of which are currently major concerns with Kenyan land data. Indeed, there is evidence that that processes of digitisation and computerisation of records, and land reforms generally, have been thwarted severally by interested parties and cartels (Kariuki, 2017). Accordingly, the Computer and Cybercrimes Bill of 2017 (Republic of Kenya, 2017) needs to become law, so as to prevent fraud and address other vulnerabilities in respect of land-mapping. It is also necessary to to fast-track the enactment of the Data Protection Bill of 2013, to deal with privacy concerns. To support the use of drones, there is need for capacity building beyond traditional disciplines such as survey and the use of multidisciplinary approaches to capture land information. The Ministry responsible for land can also apply for allocation of spectrum to enable it deploy technology effectively.

Land information management in Kenya is currently unreliable and inaccessible. Efficient and effective land information management can improve security of land rights in Kenya and neutralise land cartels and intermediaries who act as gatekeepers in Land Registries and open the way for corruption. While technology is not a silver bullet or a panacea, and indeed can be manipulated - as fraud in Kenya's Integrated Financial Management Information System (IFMIS) has shown (Okoth, 2017) properly managed use of drones can improve the reliability of land information in Kenya, thus contributing to more secure land rights, more investment, and fewer opportunities for fraud.

\section{References}

Association for Progressive Communications (APC). (2014). Global information society watch 2014: Communications surveillance in the digital age. Retrieved from http://giswatch. org/2014-communications-surveillance-digital-age

Achuka, V. (2016, December 24). Dispute over Nairobi property creates confusion over who is responsible for alleged vandalism. Daily Nation.

Agoya, V. (2016, October 6). Moi in court over disputed prime Nairobi land sale. Daily Nation. Almenteros, M. I., Arnante, A., \& Dealca, R. L. (2016). Drones: A gamechanger in land surveying and titling. Quezon City, Philippines: Foundation for Economic Freedom (FEF). Retrieved from http://landrightsph.org/resources/news-and-events/dronesa-gamechanger-in-land-surveying-and-titling/ 
Andae, G. (2015, January 19). Defence ministry to regulate use of drones on safety fears. Business Daily.

Andae, G. (2016, August 14). Kenya drone licence seekers hit 1,000. Business Daily.

Asian Survey and Mapping. (2016, July 11). Philippines accelerate land mapping with drones. Retrieved from https://asmmag.com/features/feature/11197-philippinesaccelerate-land-mapping-with-drones.html

Ayodo, H. (2014, February 21). Manual land records a nightmare. Standard Digital.

BBC News. (2013, November 7). Kenya launches Huduma e-centre to cut bureaucracy.

Besley, T., \& Ghatak, M. (2009). Property rights and economic development. In D. Rodrik, \& M. Rosenzweig (Eds.), Handbook of development economics (pp. 4525-4595). London: Elsevier. https://doi.org/10.1016/b978-0-444-52944-2.00006-9

Bonyo, K. (2015, June 4). Everything you need to know about drones in Kenya. Blog post. Retrieved from http://www.kenbonyo.com/everything-you-need-to-know-aboutdrones-in-kenya/

Business Daily. (2015, February 12). Editorial: Digitisation of land records must succeed at all costs. Retrieved from http://www.businessdailyafrica.com/analysis/Digitisation-ofland-records-must-succeed-at-all-costs/539548-2622044-2x1c5v/index.html

Cisco. (2009, July 23). Seacom goes live. Retrieved from https://newsroom.cisco.com/pressrelease-content?type =webcontent\&articleId $=5035494$

Dolson, D., Hahn, N., Palminteri. S., Dinerstein, E., Konuche, J., Chang'a, A., Keyyu, J., Mwakatobe, A., \& Goss, A. (2016). Farmer-elephant coexistence: Unmanned aerial vehicles (UAVs) for Reducing elephant crop-raiding. Azle, TX: International Elephant Foundation.

Daily Nation. (2017, January 16). Hasten digitization of all land records.

Famy Care Limited v Public Procurement Administrative Review Board E another E 4 others, 2013 eKLR (High Court 2013).

Global Spatial Data Infrastructure Association (GSDI). (2016, March 22). Kenya: New Geo-Spatial Data Centre to house National Spatial Data Infrastructure Secretariat.

Gordon Institute of Business Science (GIBS). (2013). Digital disruption: Changing the rules of business for a hyper-connected world. Authored with Dimension Data. University of Pretoria.

Ihucha, A. (2014, November 15). Tanzania now bans private drones from overflying its national parks, cites security. The East African.

Internet World Stats. (2016). Africa 2016 population and Internet users statistics for 2016.

Johnson, E. (2015, December 15). Kenya basically bans all drone use - despite potential benefits they may yield. Retrieved from http://www.pri.org/stories/2015-12-15/kenyabasically-bans-all-drone-use-despite-potential-benefits-they-may-yield

Kameri-Mbote, P.(2016). Kenya land governance assessment framework report (LGAF). Nairobi: World Bank. https://doi.org/10.1596/28502

Kameri-Mbote, P., \& Kindiki, K. (2008). Trouble in Eden: How and why unresolved land issues landed "peaceful Kenya" in trouble in 2008. Forum for Development Studies, 35(2), 167-193. https://doi.org/10.1080/08039410.2008.9666408

Kameri-Mbote, P., Mony-Odhiambo, F., Muriungi, M., \& Nyawira, O. (2016). Spectrum management and regulation in Kenya: Engendering inclusive access to technology and information. Nairobi: Ford Foundation.

Kariuki, J. (2017, January 2). Nairobi blames ministry cartels for land theft. Daily Nation. 
Kenya Civil Aviation Authority (KCAA). (2017). The Civil Aviation (Remotely Piloted Aircraft Systems) Regulations, 2017. Retrieved from https://www.airport-uav.com/ wp-content/uploads/2016/03/RPAS-DRAFT-Regulations-2017.pdf

Kuo, L. (2017, February 14). Kenya has approved the commercial use of drones. Quartz Africa.

Retrieved from https://qz.com/910113/kenya-has-approved-the-commercial-useof-drones/

Kuria, D., Kasaine, A., Khalif, A., \& Kinoti, S. (2016). Developing a national land information management system - the Kenyan strategy. Paper presented to the Annual World Bank Conference on Land and Poverty, Washington, DC, 14-18 March.

Lindley,J.,\&Colton,P.(2016,May3).Gameofdrones.https://doi.org/10.1145/2793107.2810300

Makoye, K. (2016, September 8). Tanzania turns to drones to bring peace in bitter fight for land. Reuters.

Makoye, K. (2017, January 4). Drones help communities map flood risk in Dar es Salaam slums. Reuters.

Manske, J. (2014). Innovations out of Africa: The emergence, challenges and potential of the Kenyan tech ecosystem. Berlin: Vodafone Institute for Society and Communications.

Mbaka, J. (2013, September 3). Lands ministry to digitise records, says Charity Ngilu. Standard Digital.

Mbaria, C. N. (2009). Kenya's experience towards the establishment of land information management system: Automation of Kenya's land records. Presentation slides. Nairobi: Ministry of Lands.

Ministry of Lands. (2009). Sessional paper No. 3 of 2009 on National Land Policy. Nairobi.

Ministry of Lands and Physical Planning. (2017, January 2). Key achieved projects. Retrieved from http://www.ardhi.go.ke/?page id=216

Moime, D. (2016, April 25). Kenya, Africa's Silicon Valley, epicentre of innovation. Venture Capital for Africa. Retrieved from https://vc4a.com/blog/2016/04/25/kenyaafricas-silicon-valley-epicentre-of-innovation/

Mulaku, G. (2012). Land information management in Kenya: An integrated approach. Department of Surveying, University of Nairobi.

Murungi, M. (2011). Cyber law in Kenya. The Netherlands: Kluwer International.

Mutavi, L. (2016, December 22). High Court restrains NLC from resolving Nairobi land dispute. Daily Nation.

Muthoni, K. (2015, January 14). Disputed land belongs to Langata Road Primary School, declares Mohamed Swazuri. Standard Digital.

Mutiga, M. (2009, November 14). Digitisation of land records to attack rot at head office. Daily Nation.

Mutuku, D. (2015, July 14). How Huduma is transforming public service. Standard Digital.

Nairobi Law Monthly Company Limited v. Kenya Electricity Generating Company (KENGEN) E 6 others, 2013 eKLR (High Court 2013).

National Treasury. (2016, December 1). Tender document for digitisation of land records in various registries. Retrieved from http://supplier.treasury.go.ke/site/tenders.go/index.php/ public/tender view/9999

Ncube, M., \& Ondiege, P. (2016). Silicon Kenya: Harnessing ICT innovations for economic development. Abidjan: African Development Bank.

Ndemo, B. (2016, April 11). iHub is evolving to help more start-ups grow and compete. Daily Nation. 
Ng'aru, S. W., \& Wafula, M. K. (2015). Factors influencing the choice of Huduma Centers' services (A case study of Mombasa Huduma [Center]). International Journal of Scientific and Research Publications, 5(6), 1-9. https://doi.org/10.6007/ijarbss/v5i6/1660

Njoroge, K. (2016, March 31). Authority limits civilian drone operators to height of $400 \mathrm{ft}$. Business Daily.

Ntonjira, L. (2016). Challenges of developing land information management systems (LIMS) for county governments in Kenya. Presentation slides. 11th ESRI Eastern Africa User Conference, Nairobi: 2-4 November.

Nyassy, D. T. (2014, October 17). Probe Karen land scam, Ngilu tells ethics team. Daily Nation.

Nyongesa, L. N. (2012, January 1). GIS-based national land information management system (NLIMS). Paper for FIG Working Week 2012, Rome, 6-10 May.

Obwocha, B. (2014, November 25). Government, Safaricom sign deal for Sh15 billion security surveillance system. Daily Nation.

Odongo, R. O., \& Rodriques, A. J. (2016). Metadata models and standards for Kenya National Spatial Data Infrastructure: A case study of 12 government ministries. School of Computing and Informatics, University of Nairobi.

Ogutu, J. (2015, May 18). How ICT drives Kenya's economic growth. Standard Digital.

Okoth, E. (2017, January 8). State audit finds serious loopholes in Ifmis system. Daily Nation.

Okuku, J., Bregt, A., \& Grus, L. (2014). Assessing the development of Kenya National Spatial Data Infrastructure (KNSDI). South African Journal of Geomatics, 3(1), 95-112.

Okuttah, M. (2015, May 24). Safaricom's security system live in Nairobi, Mombasa. Daily Nation.

Olopade, D. (2014). The bright continent. New York: Houghton Mifflin Harcourt.

Ombati, C. (2016, December 5). Elderly couple violently evicted from house in Westlands, Nairobi over lease dispute. The Standard.

Omulo, C. (2017, January 15). Digitisation of Lands records to disrupt services. Daily Nation. Onoma, A. K. (2010). Endogenous contributions to institutional change. In The politics of property rights institutions in Africa (pp. 176-193). Cambridge: Cambridge University Press. https://doi.org/10.1017/cbo9780511691942.009

Pablo, M. C., \& Petzold, O. (2016). Using drone technology to improve land titling in the Philippines. Pasig, Philippines: The Asia Foundation.

Peake, A. (2013). Kenya's ICT sector, mobile money and the transformation to a middle-income country. Tokyo: Center for Global Communications (GLOCOM).

Pilling, D. (2016, April 27). Kenyans start to roam Silicon Savannah. Financial Times.

Republic of Kenya. (2004). Report of the Commission of Inquiry into the Illegal/Irregular Allocations of Land. Nairobi: Government Printer.

Republic of Kenya. (2008). First medium term plan (2008-2012): Kenya Vision 2030. Nairobi. Republic of Kenya. (2010, August 27). Constitution of Kenya 2010. Retrieved from https:// www.kenyaembassy.com/pdfs/the\%20constitution\%20of\%20kenya.pdf

Republic of Kenya. (2012, April 27). Land Registration Act 3 of 2012, Cap 300. Retrieved from http://extwprlegs1.fao.org/docs/pdf/ken112133a.pdf

Republic of Kenya. (2016, September 7). Access to Information Act 31 of 2016. Retrieved from http://kenyalaw.org

Republic of Kenya. (2017, June 13). Computer and Cybercrimes Bill, 2017. Retrieved from http://kenyalaw.org 
Smith, D. (2014, June 4). Internet use on mobile phones in Africa predicted to increase 20fold. The Guardian.

Soiselo, D. (2016, November 1). Using drones to map and model flood risks in Dar es Salaam, Tanzania. Floodlist.

Sunday, F. (2015, September 14). Safaricom banks on new spectrum to deepen its 4G services. Standard Digital.

UAV Systems International. (2016, February 1). Kenya drone laws. Retrieved from https:// uavsystemsinternational.com/drone-laws-by-country/kenya-drone-laws/

Wanzala, J. (2015, October 31). Experts: Digitising land records requires Sh10b. Standard Digital.

Wanzala, J. (2016, December 8). Nairobi County to digitise lands registry by February. Standard Digital.

Wasuna, B. (2016, August 31). Equity Bank's Mwangi joins USIU's land battle with Moi. Business Daily.

Wayumba, G. O. (2013, February 28). An evaluation of the cadastral system in Kenya and a strategy for its modernization. $\mathrm{PhD}$ thesis, University of Nairobi.

Wayumba, G. (2013). The structure of the cadastral system in Kenya. Journal of Land Administration in Eastern Africa, 1(1), 6-20.

World Bank. (2010). Kenya economic update. Edition No. 3. Washington, DC. https://doi. org/10.1596/27776

World Bank. (2016). Doing business in Kenya 2016. Retrieved from http://www.doingbusiness. org/ /media/WBG/DoingBusiness/Documents/Subnational-Reports/DB16-SubKenya.PDF

World Bank. (2016). Tanzania: Using drone technology to secure land rights. Retrieved from http://www.worldbank.org/en/news/video/2016/07/25/tanzania-using-dronetechnology-to-secure-land-rights 